\title{
THE
}

\section{Addressing the STEM Gender Gap by Designing and Implementing an Educational Outreach Chemistry Camp for Middle School Girls}

\author{
Mindy Levine \\ University of Rhode Island, m_levine@uri.edu \\ Nicole Serio \\ University of Rhode Island \\ Bhasker Radaram \\ University of Rhode Island \\ Sauradip Chaudhuri \\ University of Rhode Island \\ William ThTalbert and additional works at: https://digitalcommons.uri.edu/chm_facpubs

The University of Rhode Island Faculty have made this article openly available. \\ Please let us know how Open Access to this research benefits you.
}

This is a pre-publication author manuscript of the final, published article.

Terms of Use

This article is made available under the terms and conditions applicable towards Open Access

Policy Articles, as set forth in our Terms of Use.

\section{Citation/Publisher Attribution}

Levine, M., Serio, N., Radaram, B., Chaudhuri, S., \& Talbert, W.. (2015). Addressing the STEM Gender Gap by Designing and Implementing an Educational Outreach Chemistry Camp for Middle School Girls. Journal of Chemical Education, 92(10), 1639-1644. doi: 10.1021/ed500945g Available at: http://dx.doi.org/10.1021/ed500945g 


\section{Addressing the STEM Gender Gap by Designing and Implementing an Educational Outreach Chemistry Camp for Middle School Girls}

Mindy Levine, ${ }^{*}$ Nicole Serio, Bhasker Radaram, Sauradip Chaudhuri, and William Talbert

5 Department of Chemistry, University of Rhode Island, 51 Lower College Road, Kingston, RI 02881; mlevine@chm.uri.edu

\section{ABSTRACT}

There continues to be a persistent, widespread gender gap in multiple STEM disciplines at all educational and professional levels: from the self-reported interest of pre-school aged students in scientific exploration, to the percentages of tenured faculty in these disciplines, more men than women express an interest in science, a confidence in their scientific abilities, and ultimately more men than women decide to pursue scientific careers. Reported herein is an intensive outreach effort focused on addressing this gender gap: a full-time, week-long chemistry camp that was designed and implemented for middle school girls in the state of Rhode Island. The camp schedule included multiple hands-on experiments, field trips, and significant interactions with female scientists, all of which were designed to increase the participants' interest in and enthusiasm for science. The success of the program in changing the participants' attitudes towards science was measured through administration of a pre-camp and post-camp survey, and the survey results demonstrated a strong success in changing the participants' attitudes towards the widespread applicability of science, their perceived level of support for scientific study, and their interest in pursuing STEMrelated careers. 
ABSTRACT GRAPHIC

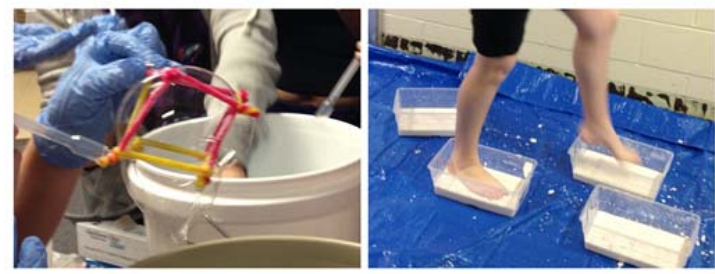

\section{KEYWORDS}

Elementary/Middle School Science, Public Understanding/Outreach, Hands-On Learning/Manipulatives, Inquiry-Based/Discovery Learning

\section{INTRODUCTION}

There is a significant dearth of female chemists at the highest levels of academia: at the top 50 schools (measured by research funding), only 18\% of tenured and tenuretrack positions were held by females in $2012-2013 .{ }^{1}$ The numbers are slightly more encouraging across all STEM disciplines at all academic institutions, with approximately $25 \%$ of full-time, full professor positions held by females in $2015 .^{2}$ Research indicates that this gender gap may start as early as elementary school, with female students having a more negative attitude towards science than males starting as early as $4^{\text {th }}$ grade. ${ }^{3,4}$ This gender gap is likely reinforced by the fact that high school science teachers spend significantly more time addressing the boys in the classroom, a fact that has been well-documented in the literature as recently as $2013.5,6$

This gender gap has a multitude of potential causes that have been investigated in the literature, including: (a) a lack of female scientist role models, ${ }^{7,8}$ which contributes to childrens' perceptions that scientists are overwhelmingly white males; ${ }^{9,10}$ (b) girls' self-perception that they lack aptitude and ability to succeed in STEM disciplines; ${ }^{11}$ and (c) teachers', parents', and other authority figures' reinforcement of these stereotypical notions. ${ }^{12,13}$ These phenomena affect children as young as 4 years old, ${ }^{14}$ and continue to affect students' attitudes, perceptions, and experiences throughout their K-12 education, ultimately culminating in significant gender gaps in college students' choices 
of majors and careers. ${ }^{15-17}$ Educators have attempted to address this gender gap through increasing girls' access to female role models, ${ }^{18-20}$ and through conducting outreach activities specifically targeted towards female students. ${ }^{21,22}$

A concurrent problem in STEM education is the lack of hands-on laboratory time in the formal middle school and high school curricula, which is attributable to a general decrease in funding for STEM education, ${ }^{23,24}$ as well as an increased prevalence of standardized testing that de-emphasizes hands-on experimental training. ${ }^{25}$ To address this issue, educators have conducted hands-on outreach workshops, ${ }^{26-28}$ developed creative methods to increase the time devoted to hands-on learning, ${ }^{29,30}$ and implemented innovative uses of technology to conduct virtual field trips ${ }^{31}$ and virtual science experiments. ${ }^{32,33}$

To simultaneously address both of these issues: the persistent gender gap in STEM disciplines and the lack of hands-on science education, we developed a full-time, weeklong chemistry camp for middle school girls in Rhode Island. Hands-on full-time outreach programs for girls have previously been reported by this ${ }^{34}$ and other journals; ${ }^{35-37}$ review articles on this topic have also been published. ${ }^{38}$ Only one of the previously reported full time programs was focused on chemistry, and in that case focused particularly on analytical chemistry experiments. Key novel elements of our reported program are the inclusion of multiple field trips, discussions with female scientist role models, and a broader range of hands-on scientific activities, including investigation of material properties through relay races on Non-Newtonian fluids.

The camp schedule included 11 hands-on scientific activities, significant interactions with female scientists, and two field trips to explore scientific issues. The main goals of the camp were to ensure that the participants understood (1) the direct relevance and applicability of science in their everyday lives, and (2) that scientists comprise a diverse demographic group. Reported herein is the development, 
implementation, and evaluation of this chemistry camp, as well as implications for future outreach efforts.

\section{CAMP OVERVIEW}

The chemistry camp was run from April 21-25, 2014, at the University of Rhode Island Kingston campus. Participants were recruited from middle schools throughout the state of Rhode Island, and 40 girls (out of a total application pool of 87 girls) were selected to participate. The camp capacity was set at 40 due to space and budgetary constraints. Of the 40 accepted girls, 36 actually attended the camp, with the other 4 girls declining to participate at the last minute. The application procedure required the girls to briefly state why they were interested in attending the chemistry camp, and what they hoped to gain from their participation. The girls were not required to have any pre-requisite knowledge; all necessary content was delivered in a short, interactive lecture prior to the start of each activity. At the conclusion of each activity, the questions in the camp booklet were answered in interactive group sessions. All funding for the camp was provided by the Dreyfus Foundation Special Grant Program in the Chemical Sciences. The supporting information to this article includes the full booklet that was provided to all camp participants, which includes a detailed background for each experiment, instructions for how to execute the experiment successfully, and postexperiment questions and points for further discussion.

Participants were responsible for arranging their own transportation to and from camp each day. In addition to the 11 major activities discussed below, students also participated in multiple swimming breaks throughout the week, watched selected science videos, and engaged in extensive interactions with invited speakers, camp volunteers, and the PI, Dr. Levine. 


\section{Participant Demographics}

The 36 participants came from communities throughout the state of Rhode Island, with the largest contingent from Pawtucket (9/36 of the girls). The participants came from public schools (17), private schools (14), charter schools (1), and home schools (4). $25 \%$ of the girls were from non-white minority groups $(9 / 36)$.

\section{HANDS-ON EXPERIMENTATION}

As mentioned in the introduction, one goal of the camp was to educate the participants about the applicability of science in their everyday lives through hands-on experimentation. This hands-on experimentation has been shown to be crucial to encouraging general interest in and enthusiasm about STEM disciplines. ${ }^{39}$ To that end, the camp schedule included 11 hands-on activities (Table 1). For each activity, the participants learned about the key scientific background, conducted the experiments, and discussed the results. Selected photographs of these activities are shown in Figure 1.
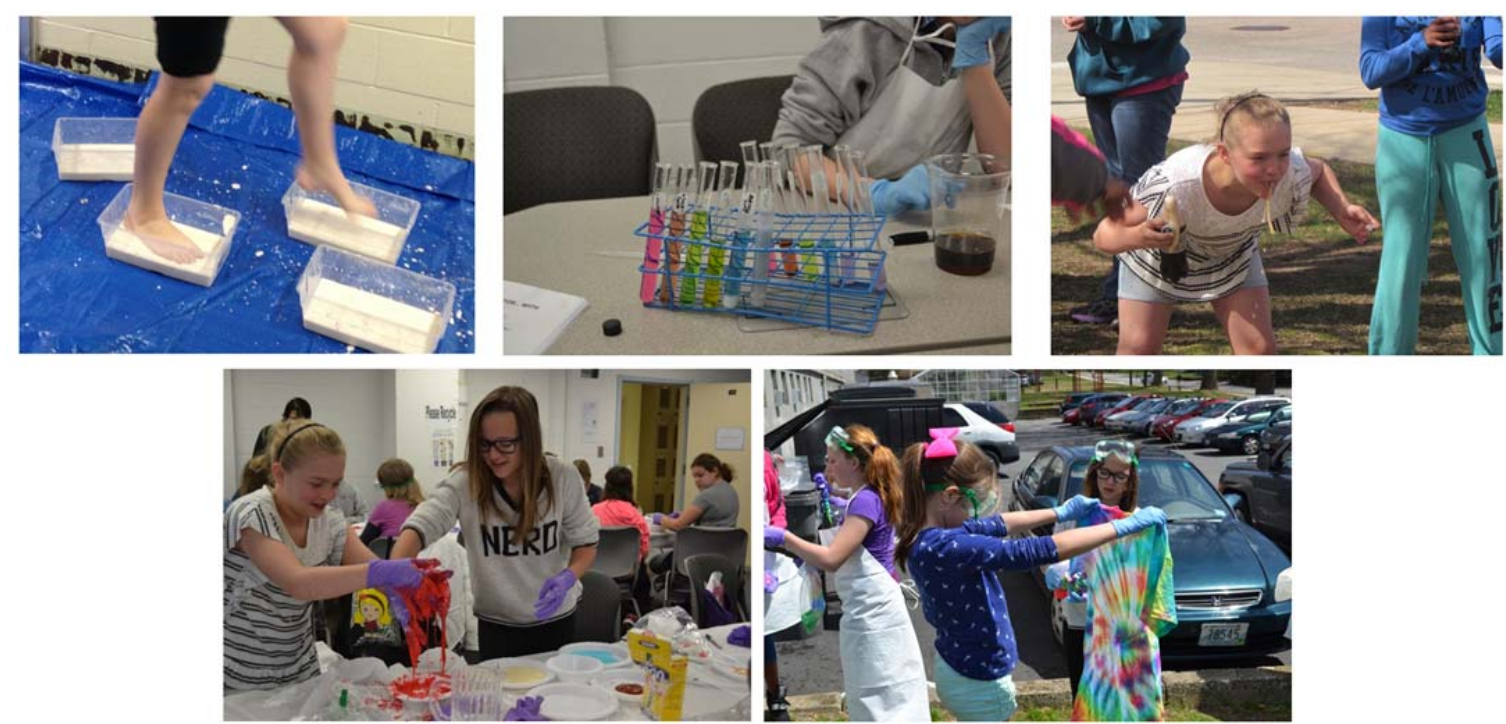

Figure 1. Photographs of hands-on scientific activities (clockwise from top left): running on corn starch in water; making a $\mathrm{pH}$ indicator from red cabbage; exploring explosions of Diet Coke and Mentos; tie-dying T-shirts; and making red-colored slime.

Table 1. Overview of Hands-On Activities

\begin{tabular}{|l|l|l|l|l|}
\hline $\begin{array}{l}\text { Activity } \\
\text { Number }\end{array}$ & Title & Activity Synopsis & Scientific Discussion & References \\
\hline
\end{tabular}




\begin{tabular}{|c|c|c|c|c|}
\hline 1 & $\begin{array}{l}\text { Polymers of } \\
\text { Everyday } \\
\text { Objects }\end{array}$ & $\begin{array}{l}\text { Isolation of the super-absorbent } \\
\text { polymer from diapers; Study of hair } \\
\text { gel properties and the "melting" of } \\
\text { hair gels through the addition of salts } \\
\text { to collapse the hydrogel }\end{array}$ & $\begin{array}{l}\text { Definition of a polymer, how } \\
\text { polymers are used }\end{array}$ & $40,41,42,43$ \\
\hline 2 & $\begin{array}{l}\text { Forensic } \\
\text { Science } \\
\text { Investigation } \\
\text { with Lipstick }\end{array}$ & $\begin{array}{l}\text { Mock forensic investigation using } \\
\text { chromatography to separate lipstick } \\
\text { pigments, to identify which fictional } \\
\text { character left a lipstick stain on a wine } \\
\text { glass }\end{array}$ & $\begin{array}{l}\text { Theory and applications of } \\
\text { chromatography }\end{array}$ & \\
\hline 3 & $\begin{array}{l}\text { Lava Lamp } \\
\text { Construction }\end{array}$ & $\begin{array}{l}\text { Construction of home-made lava } \\
\text { lamps using oil, water, salt, and food } \\
\text { coloring }\end{array}$ & $\begin{array}{l}\text { Densities of liquids, and the } \\
\text { ability of ionic compounds to } \\
\text { perturb those densities }\end{array}$ & 44 \\
\hline 4 & Square Bubbles & $\begin{array}{l}\text { Construction of "square bubbles" } \\
\text { using pipe cleaner boxes to frame } \\
\text { the bubbles, and a water-glycerin- } \\
\text { dish soap mixture to construct long- } \\
\text { lasting bubbles }\end{array}$ & $\begin{array}{l}\text { Surface tension of water and } \\
\text { how that tension is related to } \\
\text { the molecular structure of } \\
\text { water and its fundamental } \\
\text { properties }\end{array}$ & 45,46 \\
\hline 5 & Oil Spill Cleanup & $\begin{array}{l}\text { Clean-up of a mock oil spill in a fish } \\
\text { tank using a variety of materials, } \\
\text { including absorbent pads, feathers, } \\
\text { cotton balls, and super-absorbent } \\
\text { polymer }\end{array}$ & $\begin{array}{l}\text { The effects of anthropogenic } \\
\text { oil spills such as the } \\
\text { Deepwater Horizon spill of } \\
2010 \text {, and currently used state- } \\
\text { of-the-art methods for oil spill } \\
\text { cleanup and environmental } \\
\text { remediation }\end{array}$ & 47,48 \\
\hline 6 & $\begin{array}{l}\text { Jelly Fish in a } \\
\text { Bottle }\end{array}$ & $\begin{array}{l}\text { Construction of a mock jelly fish with } \\
\text { a plastic bag filled with air }\end{array}$ & $\begin{array}{l}\text { Density of gases and fluids, } \\
\text { and how the mock jelly fish } \\
\text { can float to the top of the water } \\
\text { mixture }\end{array}$ & \\
\hline 7 & $\begin{array}{l}\text { Walking on Corn } \\
\text { Starch }\end{array}$ & $\begin{array}{l}\text { Relay races across containers filled } \\
\text { with corn starch and water mixtures }\end{array}$ & $\begin{array}{l}\text { Non-Newtonian fluids and the } \\
\text { effect of pressure on those } \\
\text { fluids' properties }\end{array}$ & 49 \\
\hline 8 & $\begin{array}{l}\text { Make Your Own } \\
\text { pH Paper }\end{array}$ & $\begin{array}{l}\text { Use of red cabbage to make a pH } \\
\text { indicator, and testing of the } \mathrm{pH} \text { of } \\
\text { common household objects, } \\
\text { including bleach, vinegar, antacids, } \\
\text { and Coca-Cola }\end{array}$ & Acidity and basicity & 50 \\
\hline 9 & $\begin{array}{l}\text { Diet Coke and } \\
\text { Mentos } \\
\text { Explosions }\end{array}$ & $\begin{array}{l}\text { Adding Mentos to Diet Coke and } \\
\text { observing the explosion }\end{array}$ & $\begin{array}{l}\text { Nucleation of bubbles and the } \\
\text { chemical basis of explosions }\end{array}$ & 51 \\
\hline 10 & $\begin{array}{l}\text { Non-Newtonian } \\
\text { Fluids }\end{array}$ & Making Oobleck, Gak, and slime & $\begin{array}{l}\text { Non-Newtonian fluids and the } \\
\text { effect of pressure on those } \\
\text { fluids' properties }\end{array}$ & 52 \\
\hline 11 & $\begin{array}{l}\text { Tie-Dying T- } \\
\text { Shirts }\end{array}$ & $\begin{array}{l}\text { Tie-dying t-shirts using multiple } \\
\text { colors and patterns }\end{array}$ & $\begin{array}{l}\text { Color pigments; science of } \\
\text { dyeing clothing }\end{array}$ & 53 \\
\hline
\end{tabular}

\section{CAMP FIELD TRIPS}

Field trips are a crucial educational tool in encouraging students' interest in STEM disciplines; ${ }^{54,55}$ unfortunately, budgetary and time constraints have made field trips in 
Mystic Aquarium in Mystic, Connecticut. The Narragansett Bay Commission trip provided the girls with the opportunity to conduct hands-on water testing, tour the water treatment facility, and watch an educational video detailing the water treatment process. The Mystic Aquarium trip provided the girls with the opportunity to learn about the science of marine ecosystems and marine life, as well as to conduct a handson squid dissection.

\section{FEMALE ROLE MODELS}

Literature has shown that one reason that girls and women at all educational levels lose interest in the STEM fields is the lack of female role models. ${ }^{57-59}$ To address this issue, the camp schedule provided ample interactions with female scientists, including: Dr. Stefanie Sydlik, a post-doctoral research fellow at Massachusetts Institute of Technology; Professor Mindy Levine, an assistant chemistry professor at the University of Rhode Island, and female graduate students and undergraduate students in the chemistry department at the University of Rhode Island. The interactions with female scientists included a brief presentation by Dr. Sydlik about her career, her goals, and what her daily work entails, followed by an extensive, participant-directed question and answer session. The participants also had ample informal question and answer time with Dr. Levine and the other graduate students throughout the week.

\section{EVALUATION}

As mentioned in the introduction, a key goal of the chemistry camp was to demonstrate the applicability of science in the girls' daily lives, and to educate them about possibilities for females to pursue STEM careers. Our success in achieving this goal was evaluated through administering pre-camp and post-camp surveys to all camp participants. The survey questions were selected from published surveys that measured students' attitudes about science relevance, ${ }^{60}$ and in particular asked the participants to rate their responses to the questions shown in Table 2 on a scale of $1-5(1=$ strongly 
agree; $5=$ strongly disagree). Asterisks next to the question numbers indicate those questions that had the most significant differences in responses pre- and post-camp.

The results of this survey are summarized in Table 2. A paired t-test conducted on this data gave a two-tailed P value less than 0.0001 for the cumulative survey scores, considered to be extremely statistically significant. Several of these results merit further discussion: (1) For all questions, the average responses were higher at the start of the week than at the end of the week, meaning that more of the girls agreed with these statements after participating in the chemistry camp. This trend reflects the desired outcome for most of the survey questions; for example, more girls agreed that, "Science will help me to understand the effect I have on the environment," (1.89 pre-camp; 1.32 post-camp), and that, "Science can help me to make better choices about various things in my life" (2.14 pre-camp; 1.71 post-camp). However, more girls also agreed with the statement that, 'I do not expect to use science much when I get out of school,' although that difference was among the smallest of the questions asked (difference $=0.32$ ), and it also had the highest absolute value both pre- and post-camp (3.86 and 3.54, respectively), indicating most of the participants disagreed or strongly disagreed with that statement.

Table 2. Survey responses pre- and post-camp participation

\begin{tabular}{|l|l|l|l|l|}
\hline & & \multicolumn{2}{l|}{$\begin{array}{l}\text { Average Survey Response } \\
\text { Scores, }{ }^{b}=28^{c}\end{array}$} & Difference \\
\hline $\begin{array}{l}\text { Item } \\
\text { number }\end{array}$ & Survey Statements for Response ${ }^{a}$ & Pre-Camp & Post-Camp & \\
\hline $\mathbf{1}$ & $\begin{array}{l}\text { Science will help me to understand the effect I have on the } \\
\text { environment. }\end{array}$ & 1.89 & 1.32 & 0.57 \\
\hline $\mathbf{2}$ & Science helps me to ask others for help with my work. & 2.71 & 2.25 & 0.46 \\
\hline $\mathbf{3}$ & Using scientific methods helps me think things through. & 1.89 & 1.54 & 0.36 \\
\hline $\mathbf{4}$ & Science can help me decide how to treat my cold or illness. & 2.36 & 1.71 & 0.64 \\
\hline $\mathbf{5}^{*}$ & $\begin{array}{l}\text { Usually, it is bad to have any feelings about the scientific issues I } \\
\text { am considering. }\end{array}$ & 3.75 & 3.04 & 0.71 \\
\hline $\mathbf{6}$ & Science should be required in school. & 1.61 & 1.36 & 0.25 \\
\hline $\mathbf{7}^{*}$ & Science could help me figure out how to spin/shoot/throw/hit a ball. & 2.71 & 1.96 & 0.75 \\
\hline $\mathbf{8}$ & Science class helps me to evaluate my own work. & 2.32 & 1.71 & 0.61 \\
\hline $\mathbf{9}$ & I do not expect to use science much when I get out of school. & 3.86 & 3.54 & 0.32 \\
\hline $\mathbf{1 0}$ & I am interested in a career as a scientist or engineer. & 2.68 & 2.18 & 0.50 \\
\hline
\end{tabular}




\begin{tabular}{|l|l|l|l|l|}
\hline $\mathbf{1 1}$ & $\begin{array}{l}\text { Making decisions can be difficult when I don't understand the } \\
\text { choices. }\end{array}$ & 1.82 & 1.39 & 0.43 \\
\hline $\mathbf{1 2}$ & My intuition helps me make decisions in science. & 2.61 & 1.89 & 0.71 \\
\hline $\mathbf{1 3}$ & I have support from others to excel at science. & 2.18 & 1.71 & 0.46 \\
\hline $\mathbf{1 4}$ & Using scientific methods helps me decide what to buy in the store. & 3.25 & 2.50 & 0.75 \\
\hline $\mathbf{1 5}$ & Science will help me understand the importance of recycling. & 2.04 & 1.46 & 0.57 \\
\hline $\mathbf{1 6}$ & $\begin{array}{l}\text { Learning science can help me understand about things that affect } \\
\text { people's health. }\end{array}$ & 1.89 & 1.43 & 0.46 \\
\hline $\mathbf{1 7}$ & $\begin{array}{l}\text { Science can help me to make better choices about various things in } \\
\text { my life (e.g., food to eat, car to buy). }\end{array}$ & 2.14 & 1.71 & 0.43 \\
\hline
\end{tabular}

${ }^{a}$ See ref 60 .

${ }^{b}$ The scale for the survey item response scores is $1-5$, with 1 indicating "strongly agree" and 5 indicating "strongly disagree".

$170{ }^{c} 28$ of the 36 participants consented to participate in this study; the results reported herein are based only on the surveys of the 28 consenting participants.

(2) The questions with the greatest pre-camp to post-camp differential were, "Science can help me figure out how to spin/shoot/throw/hit the ball" (Question 7), and "Using scientific methods helps me decide what to buy in the store" (Question 14), with an 0.75 differential pre-camp to post-camp measured for both of these questions. Interestingly, both of these questions directly address the applicability of science in daily life, and particularly in areas that are not traditionally considered to fall in the scientific realm. The dramatic change in the girls' responses in a one-week time period indicate the success of the program in teaching the participants that science is relevant to a wide range of topics.

(3) One key goal of the camp was to encourage the girls' interest in STEM disciplines and STEM careers. The successful realization of that goal was evident in the response to Question 13, which asked about the girls' perceived support for excelling at science (pre-camp: 2.18; post-camp: 1.71). Moreover, the girls' interest in pursuing a career in STEM disciplines also increased (pre-camp: 2.68; post-camp 2.18).

Overall, the survey results demonstrate measurable changes in the attitudes of the camp participants towards science, and in particular demonstrate their increased appreciation for the applicability of science in several diverse areas of life. These changes are even more noteworthy given the short time frame (only 5 days) that elapsed 
between the two administered surveys, and are a positive indication that analogous outreach efforts can have measurable beneficial effects.

CONCLUSIONS AND FUTURE DIRECTIONS

Reported herein is the design, implementation, and evaluation of a full-time, weeklong outreach program targeting middle school girls in the state of Rhode Island. This program consisted of multiple components, including hands-on experiments, field trips, and interactions with female scientists, each of which was designed to increase the girls' excitement for and appreciation of science. Survey results demonstrate that participation in the program did in fact have the desired effect in enhancing such excitement and appreciation, as well as the girls' interests in pursuing STEM-related careers. Moreover, each component of the program (each experiment, trip, or female scientist discussion) can be run as an independent event, and is also likely to increase the participants' excitement for and exposure to science.

One unanswered question is whether the positive effects observed in the survey responses will persist long-term, with girls who have participated in this program maintaining their scientific enthusiasm over subsequent months and years. Future efforts will focus on conducting follow-up surveys of the program participants, to track their long-term interest in science, as well as their choice of college, college major, and future career. In future years, we will also administer more detailed surveys to

210 elucidate the effects of each aspect of this program (experiments, field trips, and scientist interactions) on impacting girls' attitudes about science. This ongoing outreach activity at the University of Rhode Island is currently being funded by private and corporate donations. 
A full schedule of the chemistry camp program for the week, all information that was provided to the participants, copies of the registration form and IRB permission forms given to both participants and their parents/guardians. This information can be found free of charge at http://pubs.acs.org

\section{AUTHOR INFORMATION}

*E-mail: mlevine@chm.uri.edu; mindy.levine@gmail.com

\section{ACKNOWLEDGMENT}

Funding is acknowledged from the Dreyfus Foundation Special Grant Program in the Chemical Sciences

(1) Rovner, S. L. Women Faculty Positions Edge Up. Chemical and Engineering News 2014, 92, 41-44.

(2) Women, Minorities, and Persons with Disabilities in Science and Engineering. National Center for Science and Engineering Statistics Report by the National Science Foundation 2015; http://www.nsf.gov/statistics/2015/nsf15311/nsf15311.pdf

(3) Unfried, A.; Faber, M.; Wiebe, E. Gender and Student Attitudes toward Science, Technology, Engineering, and Mathematics. The Friday Institute for Educational Innovation at North Carolina State University 2014, http:/ / miso.ncsu.edu/wp-content/uploads/2014/08/AERA2014-paper-Student-Attitudes-Toward-STEM.pdf.

(4) Nosek, B. A.; Smyth, F. L.; Sriram, S. N.; Lindner, N. M.; Devos, T.; Ayala, A.; Bar-Anan, Y.; Bergh, R.; Cai, H.; Gonsalkorale, K.; Kesebir, S.; Maliszewski, N.; Neto, F.; Olli, E.; Park, J.; Schnabel, K.; Shiomura, K.; Tulbure, B. T.; Wiers, R. W.; Somogyi, M.; Akrami, N.; Ekehammar, B.; Vianello, M.; Banaji, M. R.; Greenwald, A. G. National Differences in GenderScience Stereotypes Predict National Sex Differences in Science and Math Achievement. Proc. Natl. Acad. Sci. U.S.A. 2009, 106 (26), 10593-10597.

(5) Shumow, L.; Schmidt, J.A. Academic Grades and Motivation in High School Science Classrooms Among Male and Female Students: Associations with Teachers' Characteristics, Beliefs and Practices. J. Education Research 2013, 7, 53-72. 
(6) Shumow, L.; Schmidt, J.A. Enhancing Adolescents' Motivation for Science: Research-Based Strategies for Teaching Male and Female Students. In APA's Classroom Insights From Educational Psychology Series, (series editor, D. Meyer \& L. A. Anderman) 2014. Thousand Oaks, CA: Corwin Press.

(7) Stout, J. G.; Dasgupta, N.; Hunsinger, M; McManus, M. A. STEMing the Tide: Using In-Group Experts to Inoculate Women's Self-Concept in Science, Technology, Engineering, and Mathematics (STEM). J. Personality Social Psych. 2011, 100 (2), 255-270.

(8) Hill, C.; Corbett, C.; St. Rose, A. Why So Few? Women in Science, Technology, Engineering and Math. AAUW Report 2010.

(9) Chambers, D. W. Stereotypic Images of the Scientist: The Draw-A-Scientist Test. Sci. Educ. 1983, $67(2), 255-265$.

(10) Finson, K. D.; Beaver, J. B.; Cramond, B. L. Development and Field Test of a Checklist for the Draw-A-Scientist Test. School Sci. Math. 1995, 95 (4), 195-205.

(11) Guimond, S.; Roussel, L. Bragging About One's School Grades: Gender Stereotyping and Students' Perception of Their Abilities in Science, Mathematics, and Language. Social Psych. Educ. 2011, 4 (3-4), 275-293.

(12) Liben, L. S.; Coyle, E. F. Developmental Interventions to Address the STEM Gender Gap: Exploring Intended and Unintended Consequences. Adv. Child Development Behavior. 2014, $47,77-115$.

(13) Voyles, M. M.; Fossum, T.; Haller, S. Teachers Respond Functionally to Student Gender Differences in a Technology Course. J. Res. Sci. Teaching. 2008, 45 (3), 322-345.

(14) Martin, C. L.; Ruble, D. Children's Search for Gender Cues: Cognitive Perspectives on Gender Development. Curr. Directions Psychol. Sci. 2004, 13 (2), 67-70.

(15) Dabney, K. P.; Tai, R. H. Factors Associated with Female Chemist Doctoral Career Choice Within the Physical Sciences. J. Chem. Educ. 2014, 91 (11), 1777-1786.

(16) Chipman, S. F.; Krantz, D. H.; Silver, R. Mathematics Anxiety and Science Careers Among Able College Women. Psych. Sci. 1992, 3 (5), 292-295. 
(17) Lips, H. M. Gender-and Science-Related Attitudes as Predictors of College Students' Academic Choices. J. Vocational Behavior. 1992, 40 (1), 62-81.

(18) Bamberger, Y. M. Encouraging Girls into Science and Technology with Feminine Role Model: Does This Work? J. Sci. Educ. Technol. 2014, 23 (4), 549-561.

(19) Karukstis, K. K.; Gourley, B. L.; Wright, L. L.; Rossi, M. Mentoring Strategies to Recruit and Advance Women in Science and Engineering. J. Chem. Educ. 2010, 87 (4), 355-356.

(20) Hill, O. W.; Pettus, W. C.; Hedin, B. A. Three Studies of Factors Affecting the Attitudes of Blacks and Females Toward the Pursuit of Science and Science-Related Careers. J. Res. Sci. Teaching. 1990, 27 (4), 289-314.

(21) Moser, F. Promotion of Science Among Youngsters: Chemistry Outreach Initiatives at EPFL. Chimia. 2012, 66 (11), 826-831.

(22) Gardea, J.; Rios, L.; Pal, R.; Gardea-Torresdey, J. L.; Narayan, M. From Folklore to Molecular Pharmacophores: Cultivating STEM Students among Young, First-Generation Female Mexican-Americans. J. Chem. Educ. 2011, 88 (1), 41-43.

(23) Gonzalez, H. B. An Analysis of STEM Education Funding at the NSF: Trends and Policy Discussion. Congressional Research Service Report 2012.

(24) Office of the President. Prepare and Inspire: K-12 Education in Science, Technology, Engineering, and Math (STEM) for America's Future. President's Council of Advisors on Science and Technology 2010.

(25) Strauss, V. The Washington Post Blog. http://www.washingtonpost.com/blogs/answersheet/post/how-standardized-tests-are-affecting-publicschools/2012/05/17/gIQABH1NXU_blog.html. (accessed Dec 2014).

(26) Houck, J. D.; Machamer, N. K.; Erickson, K. A. Graduate Student Outreach: Model of a OneDay "Chemistry Camp" for Elementary School Students. J. Chem. Educ. 2014, 91 (10), 16061610.

(27) Skluzacek, J. M.; Harper, J.; Herron, E.; Bortiatynski, J. M. Summer Camp to Engage Students in Nutritional Chemistry Using Popular Culture and Hands-On Activities. J. Chem. Educ. 2010, 87 (5), 492-495. 
(28) Thomas, C. L. Assessing High School Student Learning on Science Outreach Lab Activities. J. Chem. Educ. 2012, 89 (10), 1259-1263.

(29) Taraban, R.; Box, C.; Myers, R.; Pollard, R.; Bowen, C. W. Effects of Active-Learning Experiences on Achievement, Attitudes, and Behaviors in High School Biology. J. Res. Sci. Teaching. 2007, 44 (7), 960-979.

(30) Swarat, S.; Ortony, A.; Revelle, W. Activity Matters: Understanding Student Interest in School Science. J. Res. Sci. Teaching. 2012, 49 (4), 515-537.

(31) Adedokun, O. A.; Hetzel, K.; Parker, L. C.; Loizzo, J.; Burgess, W. D.; Robinson, J. P. Using Virtual Field Trips to Connect Students With University Scientists: Core Elements and Evaluation of zipTrips®. J. Sci. Educ. Technol. 2012, 21 (5), 607-618.

(32) Sancho, P.; Corral, R.; Rivas, T.; Gonzalez, M. J.; Chordi, A.; Tejedor, C. A Blended Learning Experience for Teaching Microbiology. Am. J. Pharma. Educ. 2006, 70 (5), 120.

(33) Winkelmann, K.; Scott, M.; Wong, D. A Study of High School Students' Performance of a Chemistry Experiment within the Virtual World of Second Life. J. Chem. Educ. 2014, 91 (9), $1432-1438$.

(34) Robbins, M. E.; Schoenfisch, M. H. An Interactive Analytical Chemistry Summer Camp for Middle School Girls. J. Chem. Educ. 2005, 82 (10), 1486-1488.

(35) Demetry, C.; Hubelbank, J.; Blaisdell, S. L.; Sontgerath, S.; Nicholson, M. E.; Rosenthal, E.; Quinn, P. Supporting Young Women to Enter Engineering: Long-Term Effects of a Middle School Engineering Outreach Program for Girls. J. Women and Minorities Sci. Eng. 2009, 15, 119-142.

(36) Wiest, L. R. Impact of a Summer Mathematics and Technology Program for Middle School Girls. J. Women and Minorities Sci. Eng. 2004, 4, 317-339.

(37) Jayaratne, T. E.; Thomas, N. G.; Trautmann, M. Intervention Program to Keep Girls in the Science Pipeline: Outcome Differences by Ethnic Status. J. Res. Sci. Teaching 2003, 40 (4), 393-414.

(38) Valla, J. M.; Williams, W. M. Increasing Achievement and Higher-Education Representation of Under-Represented Groups in Science, Technology, Engineering, and Mathematics Fields: 
A Review of Current K-12 Intervention Programs. J. Women and Minorities Sci. Eng. 2012, 18 (1), 21-53.

(39) Pine, J.; Aschbacher, P.; Roth, E.; Jones, M.; McPhee, C.; Martin, C.; Phelps, S.; Kyle, T.; Foley, B. Fifth Graders' Science Inquiry Abilities: A Comparative Study of Students in HandsOn and Textbook Curricula. J. Res. Sci. Teaching. 2006, 43 (5), 467-484.

(40) Yaung, J.-F.; Chen, Y.-H. Coloring a Superabsorbent Polymer With Metal Ions. An Undergraduate Chemistry Experiment. J. Chem. Educ. 2009, 86 (3), 347-349.

(41) Vikrant, W. P.; Nishan, B. N.; Sandip, A. C.; Pande, S. D.; Tapar, K. K. Development and Evaluation of Cosmoceutical Hairstyling Gel. J. Pharm. Res. 2010, 3 (12), 3045-3050.

(42) Kasaai, M. R. Super-Absorbent Polymers for Hygiene Products Applications: a Review. Recent Res. Devel. Appl. Polym. Sci. 2009, 4 (Pt. 2), 269-288.

(43) Umar, Y. Polymer Basics: Classroom Activities Manipulating Paper Clips To Introduce the Structures and Properties of Polymers. J. Chem. Educ. 2014, 91 (10), 1667-1670.

(44) Gyure, B.; Janosi, I. M. Basics of Lava-Lamp Convection. Phys. Rev. E. 2009, 80 (4-2), 046307/1-046307/7.

(45) Solomon, S. D.; Rutkowsky, S. A. Chemical Demonstration Show. Chem. Educator. 2006, 11 (1), 33-37.

(46) Peckham, G. D.; McNaught, I. J. Teaching Intermolecular Forces to First-Year Undergraduate Students. J. Chem. Educ. 2012, 89 (7), 955-957.

(47) Gohlke, J. M.; Doke, D.; Tipre, M.; Leader, M.; Fitzgerald, T. A Review of Seafood Safety After the Deepwater Horizon Blowout. Environ. Health Perspectives. 2011, 119 (8) 1062-1069.

(48) McNutt, M. K.; Chu, S.; Lubchenco, J.; Hunter, T.; Dreyfus, G.; Murawski, S. A.; Kennedy, D. M. Applications of Science and Engineering to Quantify and Control the Deepwater Horizon Oil Spill. Proc. Natl. Acad. Sci. U.S.A. 2012, 109 (50), 20222-20228.

(49) Choudhury, M. D.; Chandra, S.; Nag, S.; Das, S.; Tarafdar, S. Spreading of Non-Newtonian and Newtonian Fluids on a Solid Substrate Under Pressure. J. Phys. Conference Series. 2011, 319, 012006/1-012006/12. 
(50) Stoddard, R. L.; McIndoe, J. S. The Color-Changing Sports Drink: An Ingestible Demonstration. J. Chem. Educ. 2013, 90 (8), 1032-1034.

(51) Coffey, T. S. Diet Coke and Mentos: What is Really Behind This Physical Reaction? Am. J. Physics. 2008, 76 (6), 551-557.

(52) Wagner, N. J.; Brady, J. F. Shear Thickening in Colloidal Dispersions. Phys. Today. 2009, 62 (10), 27-32.

(53) Maulik, S. R.; Mukherjee, A.; Basak, S. An Innovative Approach Towards Tie-Dye Technique. Asian Dyer 2012, 9 (3), 42, 44-45.

(54) Bell, P. Design of a Food Chemistry-Themed Course for Nonscience Majors. J. Chem. Educ. 2014, 91 (10), 1631-1636.

(55) Peterman, K. E. Field Trips Put Chemistry in Context for Non-Science Majors. J. Chem. Educ. 2008, 85 (5), 645-649.

(56) Orion, N.; Hofstein, A. Factors That Influence Learning During a Scientific Field Trip in a Natural Environment. J. Res. Sci. Teaching. 1994, 31 (10), 1097-1119.

(57) Women in STEM: A Gender Gap to Innovation. US Department of Commerce Economics and Statistics Administration. ESA Issue Brief \#04-11, 2011.

(58) Dasgupta, N.; Asgari, S. Seeing is Believing: Exposure to Counterstereotypic Women Leaders and its Effect on Automatic Gender Stereotyping. J. Experimental Social Psychology 2004, 40 (5), 642-658.

(59) Gibson, D. E. Role Models in Career Development: New Directions for Theory and Research. J. Vocational Behavior 2004, 65 (1), 134-156.

(60) Siegel, M. A.; Ranney, M. A. Developing the Changes in Attitude About the Relevance of Science (CARS) Questionnaire and Assessing Two High School Science Classes. J. Res. Sci. Teaching. 2003, 40 (8), 757-775. 